\title{
Molecular identification of caprine carriers of theileriosis in South India
}

\author{
Hitaishi V. Nagaraj ${ }^{1}$, Bindu Lakshmanan ${ }^{1 *}$, Gleeja V. Lonappan ${ }^{2}$, \\ Habeeba Shameem ${ }^{1}$, Jain Jose ${ }^{1}$, and Lucy Sabu ${ }^{1}$ \\ ${ }^{1}$ Department of Veterinary Parasitology, College of Veterinary and Animal Sciences, Mannuthy, Kerala, India \\ ${ }^{2}$ Department of Statistics, College of Veterinary and Animal Sciences, Mannuthy, Kerala, India
}

\begin{abstract}
NAGARAJ, H. V., B. LAKSHMANAN, G. V. LONAPPAN, H. SHAMEEM, J. JOSE, L. SABU: Molecular identification of caprine carriers of theileriosis in South India. Vet. arhiv 89, 367-378, 2019.
\end{abstract}

\section{ABSTRACT}

The rising prevalence of tick borne parasites and their economic impact on livestock production have often demanded better diagnostic tools and timely treatment options. The paper reports the molecular evidence of natural infections of Theileria ovis, T. lestoquardi and T. luwenshuni among goats in Kerala, south India, using PCR and RFLP. Concurrent infection of T. ovis and T. luwenshuni was also identified. Out of 150 samples studied, the PCR protocol was also found to detect a higher prevalence $(59.3 \%)$ of theileriosis when compared to the detection of piroplasms $(30 \%)$ in stained blood smears. In this study, the majority of goats were infected with T. ovis $(75.28 \%)$, followed by those with T. luwenshuni (32.58\%) and T. lestoquardi (7.86\%). A high proportion of infected goats did not show any clinical signs indicating carrier status of infection. The carrier status of animals also signals the possible risk of disease transmission to healthy stock. However, a high incidence of caprine theileriosis, with significant haematological alterations including macrocytic hypochromic anaemia and thrombocytopenia, poses a potential threat to the goat population in the event of stress. Routine monitoring should be employed in farms for early detection and treatment of carrier animals.

Key words: goats; PCR-RFLP; Theileria ovis; T. lestoquardi; T. luwenshuni; India

\section{Introduction}

Small ruminants play a vital role in sustaining the economy of the farming community in developing countries, including India. Parasitic diseases are regarded as a major constraint to animal productivity worldwide. Amongst the different parasites infecting ruminants, vector borne diseases significantly affect the health of animals resulting in anaemia, which eventually leads to reduced production and productivity (DEMESSIE

\footnotetext{
*Corresponding author:
}

Bindu Lakshmanan, Assist. Prof., Department of Veterinary Parasitology, College of Veterinary and Animal Sciences, Mannuthy, Kerala-680651, India, Phone : +91 9447486 722; Fax: +0487 2370 344; E-mail: bindul@kvasu.ac.in 
and DERSO, 2015). In India, the cost of controlling ticks and tick borne diseases has been estimated to be US\$ 498.7 million annually (GHOSH and NAGAR, 2014).

Theileriosis and anaplasmosis are the most prevalent vector borne parasitic diseases infecting ruminants in tropical and subtropical countries (UILENBERG, 1995). Though bovine theileriosis and anaplasmosis have been extensively studied in the Indian subcontinent (SREEKUMAR et al., 2000; BHATIA and SHAH, 2001; RAVINDRAN et al., 2002; NAIR et al., 2013), there is a paucity of information on these protozoan parasites infecting ovines and caprines in particular. Among the Theileria spp. that infect small ruminants, T. uilenbergi, T. lestoquardi, and T. luwenshuni are considered as highly pathogenic (UILENBERG, 1981; SCHNITTGER et al., 2000; YIN et al., 2007). Nonpathogenic or mildly pathogenic species are T. separata, T. ovis, and T. recondita (ALANI and HERBERT, 1988). Available data on the prevalence of theileriosis in sheep and goats of India are based on the results of blood smear examination. The detection of organisms by light microscopy demands considerable technical expertise and experience, and is neither sensitive to identify carrier status and subclinical infections, nor to differentiate between different species. Besides, there are increasing reports of new species of Theileria affecting small ruminants in different countries (ALTAY et al., 2007; DUH et al., 2008; LEE et al., 2016). In this context, this study was conducted to identify the Theileria species infecting goats in our country, as well as to investigate the health status of naturally infected goats.

\section{Materials and methods}

Sampling. A total of 150 blood samples from Malabari cross bred goats covering different places in Kerala, south India viz., Ernakulam, Thrissur, Palakkad and Wayanad districts, representing six agro-ecological zones of the state, were collected. The sampling was done for routine health monitoring of animals according to the institutional guidelines of the animal ethics review committee. A preliminary screening of Giemsa stained blood smears using light microscopic examination was performed. In addition, ticks were collected from the animals during examination. Clinical signs, if any, were recorded.

PCR for Theileria spp. DNA was extracted from whole blood by commercial kits (QIAGEN, Germany). The PCR protocol for amplifying the 18S rRNA gene was standardised using Theileria genus specific primers ( TF1:5'-GCA TTC GTA TTT AAC TGT CAG AGG-3' TR1:5'ATA AGG TTC ACA AAA CTT CCC TAG -3') following the method of JALALI et al., (2013) and T. luwenshuni specific primers (Tlw18 F: 5'-GAA TCG CAG CTT TTG CGG CG-3'; Tlw18 R: 5' - ATA CCC GCA TCC TAT TTA GGG$\left.3^{\prime}\right)$ as per LEE et al. (2016). A gradient PCR protocol was done in a $12.5 \mu \mathrm{L}$ reaction volume using $6.25 \mu \mathrm{L}$ of $2 \mathrm{X}$ PCR master mix (TaKaRa Bio, Japan,) 12.5 pmol each of forward and reverse primers, $2 \mu \mathrm{L}$ of template DNA and nuclease free water. A thermal 
cycling program with an initial denaturation of $94^{\circ} \mathrm{C}$ for 5 min followed by 35 cycles of denaturation $\left(94^{\circ} \mathrm{C}, 30 \mathrm{~s}\right)$, annealing $\left(57-60{ }^{\circ} \mathrm{C}\right.$ for Theileria spp. and $60-68{ }^{\circ} \mathrm{C}$ for $T$. luwenshuni; 60s) and extension $\left(72{ }^{\circ} \mathrm{C}, 60 \mathrm{~s}\right)$ followed by final extension at $72{ }^{\circ} \mathrm{C}$ for 5 min, was done in a gradient thermal cycler (Bio-Rad T100, USA). Electrophoresis was carried out using $1.5 \%$ agarose gel and viewed in gel documentation (Biorad, USA). Anaplasma spp., Babesia spp. and Trypanosoma evansi DNA that were available in the institution were used as specificity controls. A no-template control (NTC) was also used in each run. The amplicons obtained consequent to PCR were column purified and sequenced using Sanger's dideoxy nucleotide chain termination method (AgriGenome Labs Private Limited, Cochin). The sequence similarity was checked using NCBI BLASTn tool (www.blast.ncbi.nlm.nih.gov>blast) and submitted to Genbank through bankit (gb-admin@ncbi.nlm.nih.gov). Phylogenetic analysis of the 18S rRNA gene of $T$. luwenshuni, was performed with a bootstrap consensus tree inferred from 1000 replicates, using the maximum likelihood method in Dambe 5.5.24 (XIA, 2013). The corresponding gene sequence of Plasmodium falciparum was used as the outgroup.

PCR- restriction fragment length polymorphism (RFLP). The samples which were positive by PCR for Theileria spp. were further subjected to RFLP done with the enzyme Hind II (ThermoScientific, USA) for species confirmation and differentiation (JALALI et al., 2014; HITAISHI et al., 2017). Those samples which were confirmed as Theileria spp. positive were further subjected to RFLP with $V s p$ I enzyme (ThermoScientific, USA), in a dry bath incubator (Instrumex, UK) at $37^{\circ} \mathrm{C}$ for $1 \mathrm{~h}$ in a $20 \mu \mathrm{L}$ reaction mixture consisting of $10 \mu \mathrm{L}$ PCR amplicon, $2 \mu \mathrm{L}$ of $10 \mathrm{X}$ buffer, $1 \mathrm{U}$ restriction enzyme and nuclease free water, to detect and differentiate $T$. ovis and T. lestoquardi. The digested products were visualised in 3\% agarose gel.

Haematological parameters. The total leucocyte count (TLC), the volume of packed red blood cells (VPRC), haemoglobin $(\mathrm{Hb})$ concentration, and total erythrocyte count (TEC) were analysed using a fully automated analyzer (Orphee, Switzerland). Blood samples $(n=50)$ from apparently healthy animals that were disease free from organised farms in non-endemic areas were used as controls. The obtained data were analysed using the 'independent $t$-test' with the IBM SPSS statistics, version 24 software program.

\section{Results}

The blood smears examined showed typical piroplasms of Theileria spp. in 45 out of the 150 goats screened. The intra-erythrocytic piroplasms were pleomorphic, occurring mostly as round or oval and rod shaped forms. Polymerase chain reaction, targeting a partial sequence of the 18S rRNA gene, using the primer pairs TF1/TR1, yielded bright bands of approximately $872 \mathrm{bp}$ at all annealing temperatures $\left(53-60{ }^{\circ} \mathrm{C}\right)$ in known Theileria positive samples, and in the Babesia spp. positive control (Fig. 1). There was no cross amplification in any of the Anaplasma spp. / T. evansi positive controls or NTC. 
An annealing temperature of $59{ }^{\circ} \mathrm{C}$ was selected for PCR with test DNA samples. Out of the 150 samples analysed, 89 samples yielded positive PCR signals, indicating that 59.3\% animals harboured Theileria / Babesia spp. infection. Further, all the 89 samples yielded Hind II digested products of approximately 449 and 423 bp sizes, which was discernible in 12\% PAGE gel (Fig. 2), confirming the presence of Theileria spp. However, Babesia spp. was not detected in the goats in the present study. BLASTn analysis of the aligned nucleotide sequence of these amplicons revealed significant similarity with $18 \mathrm{~S}$ r RNA gene sequences of Theileria spp. Only, and they were submitted to Genbank and assigned accession no. (KY 083046).

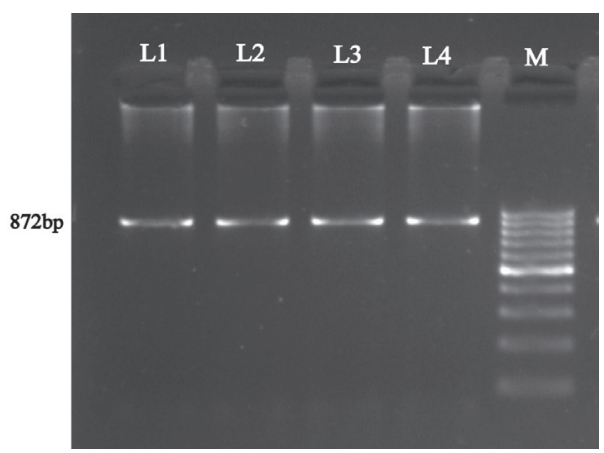

Fig. 1. Amplicons with TF1/TRI primers. M:100bp DNA ladder; Lanes L1: Theileria positive control; L2 Babesia positive control; L3-L6 : test samples; L7: NTC

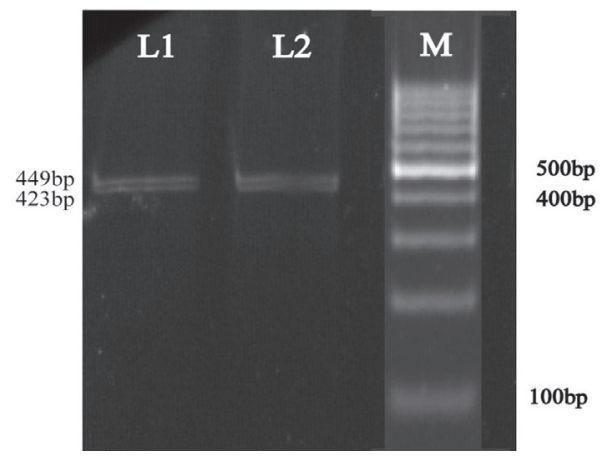

Fig. 2. Hind II digested products of Theileria spp. M:100bp DNA ladder; Lanes L1: Theileria positive control; L2- L5 : test samples

The Theileria spp. positive samples were further subjected to enzymatic digestion using Vsp I to differentiate the species. Out of the 89 positive samples, 67 samples yielded products of 92, 175 and 605 bp sizes upon digestion, which confirmed the presence of T. ovis (Fig. 3). Seven samples yielded digested products of 92 and $786 \mathrm{bp}$ in size, signalling the presence of $T$. lestoquardi (Fig. 4). The remaining 15 samples did not reveal any digested products, indicating the absence of these two Theileria species. Further, testing of all the samples with PCR employing Tlw18F/Tlw18R primer sets, specific for $T$. luwenshuni, revealed a bright band of approximately $1062 \mathrm{bp}$ in size (Fig. 5) with an annealing temperature of $62{ }^{\circ} \mathrm{C}$, in 29 samples. All the 15 samples which had not yielded $V s p$ I digested products, revealed positive signals, indicating the presence of $T$. luwenshuni. The partial sequence of the $18 \mathrm{~S}$ rRNA gene revealed 99 per cent similarity with corresponding published sequences of T. luwenshuni from different countries. The sequence was submitted to Genbank as a Kerala isolate and assigned the accession number, KY 973285. There was a concurrent infection of T. ovis and T. luwenshuni in 14 goats. 
H. V. Nagaraj et al.: Caprine carriers of theileriosis in India

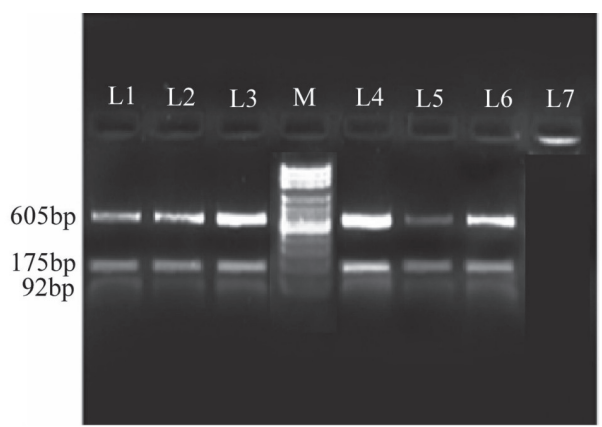

Fig. 3. VspI digested products of T. ovis. M:100bp DNA ladder; Lanes L1- L6: T. ovis positive samples; L7:Babesia positive control

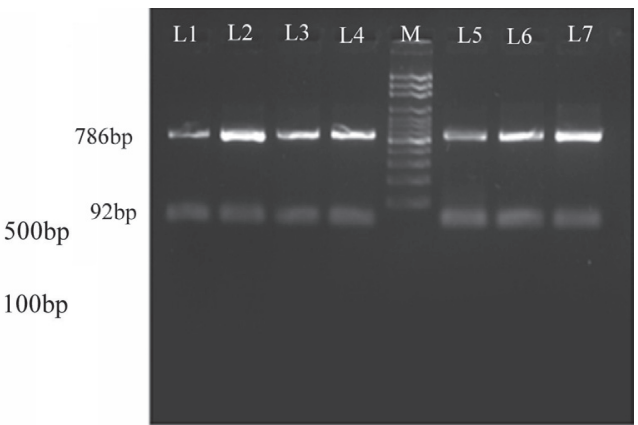

Fig. 4. VspI digested products of $T$. lestoquardi. M:100bp DNA ladder; Lanes L1L7: T. lestoquardi positive samples

Phylogenetic analysis of the partial 18S rRNA gene of T. luwenshuni, inferred using the maximum likelihood method based on the Tamura-Nei model with a 1000 bootstrap value, revealed that the Kerala isolate was closest to the UK isolate, and occurred as a sister clade to other Asian isolates (Fig. 6).

Table 1. Haematological parameters (Mean \pm SE)

\begin{tabular}{|l|r|r|c|}
\hline Parameters & Theileria positive & Control group & \multicolumn{1}{c|}{$t$} \\
\hline TLC & $13.95 \times 10^{3} \pm 1.29$ & $13.80 \times 10^{3} \pm 1.59$ & $0.76^{\text {ns }}$ \\
\hline TEC & $10.63 \pm 0.54$ & $12.39 \pm 0.95$ & $1.60^{*}$ \\
\hline Mean Hb & $8.34 \pm 0.18$ & $8.95 \pm .027$ & $1.82^{*}$ \\
\hline VPRC & $20.98 \pm 1.01$ & $20.54 \pm 1.01$ & $0.19^{\text {ns }}$ \\
\hline Mean Plt & $1.59 \times 10^{5} \pm 0.11$ & $2.45 \times 10^{5} \pm 0.25$ & $3.57^{* *}$ \\
\hline MCV & $21.85 \pm 1.67$ & $16.09 \pm 1.69$ & $2.49^{* *}$ \\
\hline MCH & $9.52 \pm 0.62$ & $7.67 \pm 0.44$ & $2.19^{* *}$ \\
\hline MCHC & $47.74 \pm 2.99$ & $58.26 \pm 6.89$ & $1.62^{*}$ \\
\hline
\end{tabular}

ns: Non significant, $* \mathrm{P}<0.05,{ }^{*} * \mathrm{P}<0.01$

Evaluation of the haematological parameters of Theileria infected goats showed that the mean TLC and VPRC values had no significant difference from those of the control group. However, the mean TEC, haemoglobin and $\mathrm{MCHC}$ values and mean platelet count were significantly decreased. The increases in $\mathrm{MCV}$ and $\mathrm{MCH}$ values were highly significant when compared with the control group (Table 1). It is noteworthy that although a significant proportion $(\mathrm{n}=56, \mathrm{P}<0.05)$ of the Theileria positive goats did not reveal 


\section{H. V. Nagaraj et al.: Caprine carriers of theileriosis in India}

any apparent clinical signs, the animals that harboured T. lestoquardi and T. luwenshuni exhibited pyrexia, anorexia, pale mucosa and inconsistent lymphadenopathy.

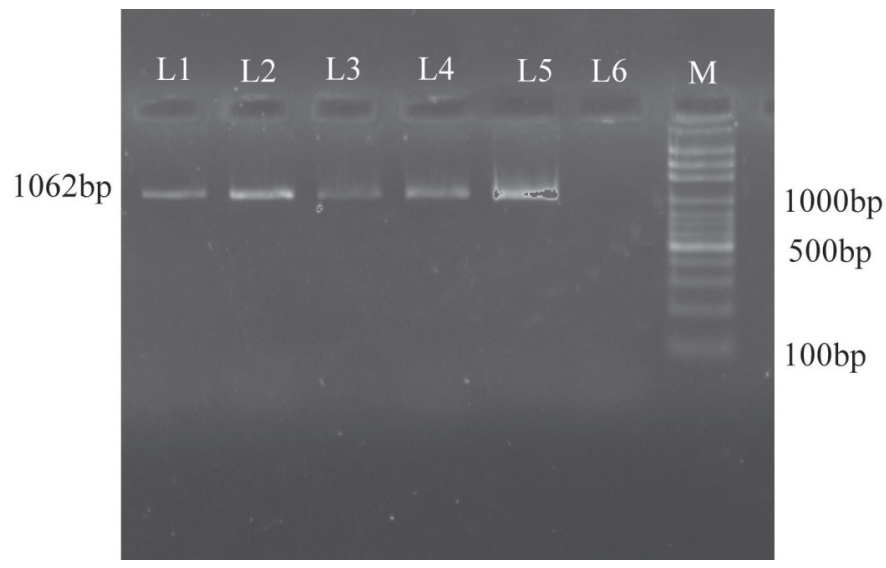

Fig. 5. Amplicons of T. luwenshuni. M:100bp DNA ladder; Lanes L1- L5: T. luwenshuni positive samples; L6-NTC

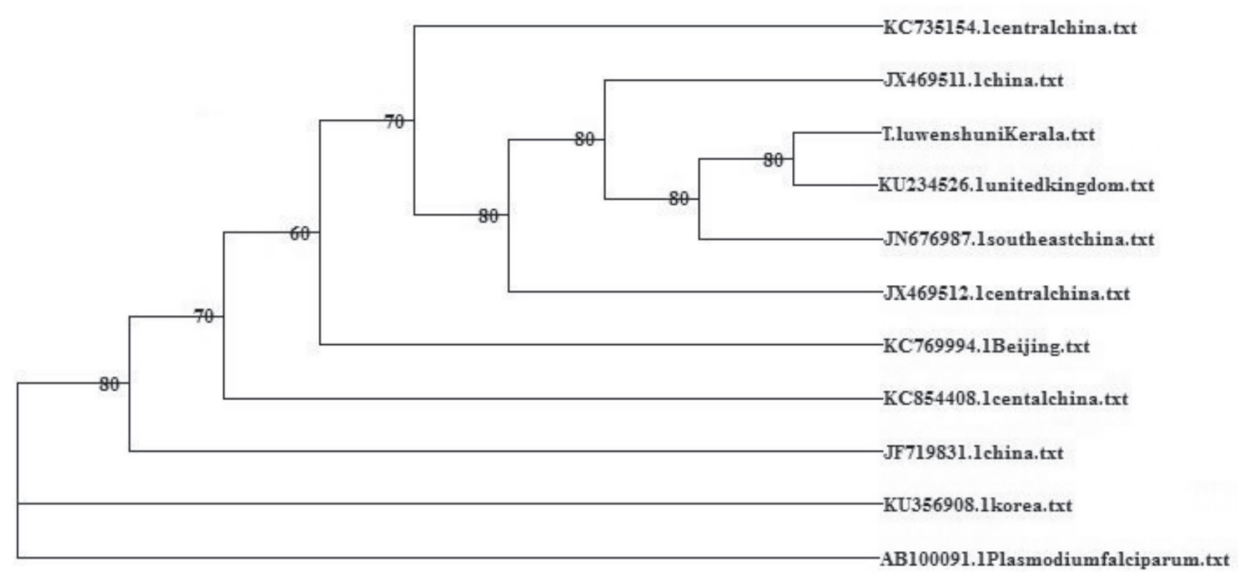

Fig. 6. Phylogenetic tree of T. luwenshuni

The PCR protocol was also found to detect a higher prevalence (59.3\%) of theileriosis when compared to the detection of piroplasms $(30 \%)$ in stained blood smears. The majority of animals (28 out of 45) that revealed piroplasm of Theileria spp. in blood smears were clinically ill. 


\section{Discussion}

Microscopic examination of Giemsa stained blood smears of goats revealed intraerythrocytic piroplasms of Theileria spp. which were pleiomorphic, occurring mostly as round or oval and rod forms, as described by LEVINE (1984). Reports of theileriosis in goats from different parts of India, based on the results of light microscopic examination, indicated a prevalence ranging from 1-22\% (ANUMOL et al., 2011; RATHUR et al., 2015; VELUSAMY et al., 2015). This clearly indicates the endemic nature of the disease in the country. However, identification of Theileria spp. based on piroplasm detection by light microscopy is consistently difficult (LEVINE, 1984).

PCR-RFLP analysis with the Hind II enzyme, that recognizes the 5'-GTYRAC- 3' sequence present in the $18 \mathrm{~S}$ rRNA gene of Theileria spp. (JALALI et al., 2014), detected a higher prevalence $(59.3 \%)$ of theileriosis in goats when compared to conventional microscopic detection, highlighting the enhanced efficiency of molecular detection tools. In addition, the low parasitaemia during subclinical infection causes difficulty in the identification of organisms by light microscopy. Microscopic examination could detect infection mostly in clinically infected animals, whereas with PCR a higher number of apparently healthy animals were also detected as positive. This finding suggests the superiority of PCR in detecting sub-clinical status and/or carrier status of theileriosis (ALTAY et al., 2005; RAZMI and YAGHFOORI, 2013). Adoption of a sensitive molecular detection tool, such as PCR- RFLP, will not only throw light on the true prevalence of infection, but also help in accurate disease diagnosis, which is imperative for sustainable disease control.

In the present study, none of the goats harboured Babesia spp. In India, the occurrence of Babesia spp. among goats is as low as $0.14 \%$ in the north (RATHUR et al., 2015) and $1.6 \%$ in the south (ANUMOL et al., 2011). The relatively low prevalence of caprine babesiosis needs detailed investigation to substantiate the suggestion that small ruminants are endemically unstable for Babesia spp. and that animals that have recovered from infection are immune (JATAU et al., 2011; ADAMU et al., 2012). Elucidation of the species of Theileria infecting goats is of utmost importance, not only in understanding the pathogenesis of infection, but also in epidemiological studies of haemoparasites in a particular geographical area. In this study, the majority of goats were infected with T. ovis (75.28\%), followed by those with T. luwenshuni $(32.58 \%)$ and T. lestoquardi $(7.86 \%)$. Recently T. luwenshuni was recorded in an outbreak of theileriosis in small ruminants in Karnataka State, India (MAMATHA et al., 2017). This is a novel Theileria species, which is as pathogenic as T. lestoquardi (ALTAY et al., 2005; LI et al., 2014). This is the first report of the species spectrum of Theileria in goats in India using molecular tools.

The genetic diversity of Theileria spp. can be efficiently unravelled by phylogenetic analysis of the 18S rRNA gene of the piroplasm (ALTAY et al., 2005; DUH et al., 2008; 


\section{H. V. Nagaraj et al.: Caprine carriers of theileriosis in India}

LI et al., 2014). The phylogenetic analysis of the T. luwenshuni sequence obtained in the present study revealed that the Kerala isolate shared the closest evolutionary relationship with the United Kingdom isolate and occurred as a sister clade to most of the Asian isolates (Fig. 6). It was farthest from Korean isolate that was isolated from deer keds, and speculated to be transmitted among ticks, keds and mammals (LI et al., 2014).

A preliminary attempt was made to analyze the health status of goats infected with theileriosis, although the majority of animals that were tested positive by PCR, were without any evident clinical signs. The mean TEC and $\mathrm{Hb}$ values of Theileria positive goats were significantly lower than those of the control animals. However, without statistically significant alterations in VPRC, the mean MCV value in Theileria positive animals showed a remarkable increase, indicating the presence of immature erythrocytes and regenerative anaemia. In the presence of an increased number of reticulocytes, that continue synthesizing haemoglobin although they do not attain the cellular haemoglobin concentration of mature RBCs, a detectable decrease in MCHC could occur (THRALL, 2012). Due to the excessive destruction of RBCs or excessive production of immature erythrocytes, the average mass of haemoglobin per $\mathrm{RBC}(\mathrm{MCH})$ will be increased (SCHALM et al., 2010). Macrocytic hypochromic anaemia was evident in infected goats in the present study, as also observed by JATAU et al., (2011); ADAMU et al., (2012) and KHAKI et al. (2015). The significantly low mean platelet values of goats infected with Theileria spp. could be due to the increased platelet destruction that commonly results from enhanced phagocytosis of platelets consequent to the increased activity of monocyte- macrophage or immune mediated mechanisms (THRALLet al., 2012), decreased bone marrow production or consumption due to extensive endothelial damage (PANTANOWITZ, 2002).

Malignant ovine theileriosis is a lympho-proliferative disease characterised by swollen lymph nodes (EL IMAM and TAHA, 2015). The very low prevalence of T. lestoquardi among Theileria positive goats, observed in the present study population, might explain the reason for the absence of leucocytosis. Although T. ovis is regarded as a relatively less pathogenic species (UILENBERG, 1995), the relative preponderance of this pathogen is not without any physiological alterations. It is noteworthy that, despite the absence of clinical evidence of illness in the majority (62.9\%) of animals positive for Theileria by PCR-RFLP, the existence of macrocytic hypochromic anaemia, with thrombocytopenia, cannot be ignored. The infection could lead to morbidity that could have an adverse impact on the production performance of animals. However, the production parameters of the animal were not assessed in the present study population. Moreover, the possibility of the goats being resilient to the clinical effects of these pathogens needs to be investigated further. There is also a possibility of subclinical/carrier infection which needs special attention, especially during exposure to several stressors such as adverse climate, high production, concurrent infection or vaccination. Besides, it also throws light on the carrier 
status of haemoparasitic infection among goats, which is a potential source of infection for the susceptible healthy population (CALLOW, 1984).

\section{Acknowledgements}

The financial support from Government of Kerala through State Plan Fund 16-17 [RSP/16-17/VI-16] and technical support of Kerala Veterinary and Animal Sciences University are gratefully acknowledged.

\section{References}

ADAMU, B., L. SAMAIL-BALARABE, L. MUSA (2012): Prevalence of haemoparasites of sheep and goats slaughtered in Bauchi Abattoir. Int. J. App. Biol. Res. 4, 128-133.

ALANI, A. J., I. V. HERBERT (1988): Pathogenesis of infection with Theileria recondita (Wales) isolated from Haemaphysalis punctata from north wales. Vet. Parasitol. 4, 293-301. DOI: 10.1016/0304-4017(88)90076-3

ALTAY, K., N. DUMANLI, M. AKTAS (2007): Molecular identification, genetic diversity and distribution of Theileria and Babesia species infecting small ruminants. Vet. Parasitol. 147, 161-165.

DOI: 10.1016/j.vetpar.2007.04.001

ALTAY, K., N. DUMANTI, P. J. HOLMAN, M. AKTAS (2005): Detection of Theileria ovis in naturally infected sheep by nested PCR. Vet. Parasitol. 127, 99-104.

DOI: 10.1016/j.vetpar.2004.09.012

ANUMOL, J., P. V. TRESAMOL, M. G. SARANYA, K. VIJAYAKUMAR, M. R. SASEENDRANATH (2011): A study on aetiology of anemia in goats. J. Vet. Anim. Sci. 42, 61-63.

BHATIA, B. B., H. L. SHAH (2001): Protozoa and protozoan diseases of domestic livestock, Indian Council of Agricultural Research, New Delhi, p. 202.

CALLOW, L. L. (1984): Protozoan and rickettsial diseases. In: Australian Bureau of Animal Health, Australian Government Publishing Service, Canberra, pp. 121-216.

DEMESSIE, Y., S. DERSO (2015): Tick borne haemo parasitic diseases of ruminants: A review. Adv. Biol. Res. 9, 210-224.

DOI: 10.5829/idosi.abr.2015.9.4.9516

DUH, D., V. PUNDA-POLIC, T. TRILAR, T. AVSIC-ZUPANC (2008): Molecular detection of Theileria spp. in ticks and naturally infected sheep. Vet. Parasitol. 151, 327-331.

DOI: 10.1016/j.vetpar.2007.11.004

EL IMAM, A., K. TAHA (2015): Malignant ovine theileriosis (Theileria lestoquardi): A review. Jordan. J. Biol. Sci. 8, 165-174.

DOI: $10.12816 / 0026953$

GHOSH, S., G. NAGAR (2014): Problem of ticks and tick-borne diseases in India with special emphasis on progress in tick control research: A review. J. Vector Borne Dis. 51, 259-270. 
H. V. Nagaraj et al.: Caprine carriers of theileriosis in India

HITAISHI, V. N., BINDU LAKSHMANAN, H. SHAMEEM, E. J. PRAVEENA, K. J. JOSE, L. SABU (2017): Molecular identification of theileriosis in goats of Kerala. Int. J. Sci. Environ. Technol. 6, 1979-1984.

JALALI, S. Z. KHAKI, B. KAZEMI, M. BANDENPOUR, S. RAHBARI, M. RAZI, S. P. YASINI (2013): Molecular detection and identification of Anaplasma spp. in sheep from Anvaz, Iran. Iranian J. Vet. Res. 14, 50-56.

JALALI, S., Z. KHAKI, B. KAZEMI, S. RAHBARI, M. SHAYAN, M. BANDEHPOUR, S. P. YASINI (2014): Molecular detection and identification of Theileria species by PCR-RFLP method in sheep from Ahraz, Southern Iran. Iranian J. Parasitol. 9, 99-106.

JATAU, I. D., A. ABDULGANIYU, A. I. LAWAL, O. O. OKUBANJO, K. H. YUSUF (2011): Gastrointestinal and haemoparasitism of sheep and goats at slaughter in Kano, Northern Nigeria. J. Vet. Sci. 9, 7-11.

KHAKI, Z., S. M. JALALI, B. KAZEMI, M. R. JALALI, S. P. YASINI (2015): A study of haematological changes in sheep naturally infected with Anaplasma spp. and Theileria ovis: molecular diagnosis. Iranian J. Vet. Med. 9, 19-26.

LEE, S., K. KIM, O. KWON, Y. OCK, T. KIM, D. CHOI, D. KWAK (2016): Novel detection of Coxiella spp., Theileria luwenshuni and T. ovis endosymbionts in deer keds (Lipoptena fortisetosa). PLOS ONE. 11, 1-10.

DOI: 10.1371/journal.pone.0156727

LEVINE, N. D. (1984): Veterinary Protozoology, $1^{\text {st }}$ ed. Iowa State University, Iowa, pp. 313-328.

LI, Y., X. ZHANG, Z. LIU, Z. CHEN, J. YANG, H. HE, G. GUAN, A. LIU, Q. RIN, Q. NIU, J. LIU, J. LUO, H. YIN (2014): An epidemiological survey of Theileria infections in small ruminants in Central China. Vet. Parasitol. 200, 198-202.

DOI: org/10.1016/j.vetpar.2013.07.023

MAMATHA, G. S., R. SHRUTHI, B. M. CHANDRANAIK, P. E. D'SOUZA, P. M. THIMMAREDDY, B. P. SHIVASHANKAR, G. C. PUTTALAKSHMAMMA (2017): Molecular epidemiology and phylogenetic characterisation of Theileria luwenshuni in India: a first report. Small Rumin Res.154, 52-57.

NAIR, A. S., R. RAVINDRAN, B. LAKSHMANAN, C. SREEKUMAR, S. S. KUMAR, R. RAJU, P. V. TRESAMOL, M. B. VIMALKUMAR, M. R. SASEENDRANATH (2013): Bovine carriers of Anaplasma marginale and Anaplasma bovis in South India. Tropical Biomedicine 30, 105-112.

PANTANOWITZ, L. (2002): Mechanisms of thrombocytopenia in tick-borne diseases. Int. J. Infect. Dis. 2, 1-6.

RATHUR, S., H. TAK, D. KAKRU (2015): Seroprevalence of haemoprotozoan diseases in ruminants of Kashmir. Agril. Adv. 4, 11-13

RAVINDRAN, R., A. K. MISHRA, J. R. RAO (2002): On the high seroprevalence of bovine babesiosis in Waynad district of Kerala. J. Appl. Anim. Res. 30, 142-145.

DOI: $10.1080 / 09712119.2002 .9706377$ 
H. V. Nagaraj et al.: Caprine carriers of theileriosis in India

RAZMI, G. R., S. YAGHFOORI (2013): Molecular surveillance of Theileria ovis, Theileria lestoquardi and Theileria annulata infection in sheep and ixodid ticks in Iran. Onderstepoort J. Vet. Res. 80, 635-640.

DOI: $10.4102 /$ ojvr.v80i1.635

SCHALM, O. W., N. C. JAIN, E. J. CARROLL (2010): Veterinary Haematology, $3^{\text {rd }}$ ed. Lea and Febiger, Philadelphia, p. 807.

SCHNITTGER, L., Y. YIN, J. LUO, W. LUGWIG, P. SHAYAN, S. RAHBARI, A. VOSSHOLTMANN, J. S. AHMED (2000): Ribosomal small- subunit RNA gene- sequence analysis of Theileria lestoquardi and a Theileria species highly pathogenic for small ruminants in China. Parasitol. Res. 86, 352-358.

DOI: $10.1007 / \mathrm{s} 0004360050680$

SREEKUMAR, C., R. ANANDAN, S. BALASUNDARAM, L. JOHN (2000): Detection of Ehrlichia bovis like organism in cultured buffalo monocytes. Trop. Anim. Health Prod. 32, 67-72.

THRALL, M. A., G. WEISER, R. ALLISON, T. W. CAMPBELL (2012): Veterinary Hematology and Clinical Chemistry, Blackwell publishing Ltd, USA, p. 776.

UILENBERG, G. (1981): Theilerial species of domestic livestock. In: Advances in the Control of Theileriosis. (Irvin, A. D., M. P. Cunningham, A. S. Young, Eds.). Martinus Nijhoff, The Hague, p. 37.

DOI: $10.1007 / 978-94-009-8346-5 \_2$

UILENBERG, G., (1995): Significance of tick- borne haemoparasitic diseases to world animal health. Vet. Parasitol. 57, 19-47.

VELUSAMY, R., N. RANI, G. PONNUDURAI, P. ANBARASI (2015): Prevalence of intestinal and haemoprotozoan parasites of small ruminants in Tamil Nadu, India. Vet. World. 8, 12051209.

DOI: $10.14202 /$ vetworld.2015.1205-1209

XIA, X. (2013): DAMBE5: A comprehensive software package for data analysis in molecular biology and evolution. Mol. Biol. Evol. 30, 1720-1728.

DOI: $10.1093 / \mathrm{molbev} / \mathrm{mst} 064$

YIN, H., L. SCHNITTGER, J. X. LUO, J. AHMED (2007): Ovine theileriosis in China: a new look at an old story. Parasitol. Res. 101, 191-195.

DOI: 10.1007/s00436-007-0689-2

Received: 25 January 2018

Accepted: 3 April 2019

Vet. arhiv 89 (3), 367-378, 2019 
H. V. Nagaraj et al.: Caprine carriers of theileriosis in India

NAGARAJ, H. V., B. LAKSHMANAN, G. V. LONAPPAN, H. SHAMEEM, J. JOSE, L. SABU: Molekularna identifikacija latentnog nositelja tajlerioze u koza u južnoj Indiji. Vet. arhiv 89, 367-378, 2019.

\section{SAŽETAK}

Rastuća prevalencija parazita koje prenose krpelji i njihov utjecaj na profitabilnost stočarske proizvodnje često su zahtijevali pouzdanije dijagnostičke alate i pravodobne načine liječenja. U ovom je radu prikazana molekularna identifikacija PCR-om i RFLP-om prirodnih invazija koza oblićima Theileria ovis, T. lestoquardi i T. Luwenshuni u Kerali u južnoj Indiji. Od 150 uzoraka analiziranih PCR-om utvrđena je viša prevalencija tajlerioze $(59,3 \%)$ u usporedbi s nalazom babezija (30\%) u obojenim krvnim razmazima. U ovom je istraživanju većina koza bila invadirana vrstom $T$. ovis $(75,28 \%$ ), a zatim vrstama $T$. luwenshuni $(32,58 \%)$ i T. lestoquardi $(7,86 \%)$. Većina invadiranih koza nije pokazivala kliničke znakove tajlerioze. Također, supklinička invazija uputila je na potencijalni rizik prijenosa parazita na druge jedinke. Osim toga visoka incidencija tajlerioze u koza sa znakovitim promjenama u krvnim pokazateljima, uključujući makrocitnu hipokromnu anemiju i trombocitopeniju, potencijalna je prijetnja zdravlju koza u stresnim stanjima. Na farmama bi trebalo uvesti rutinsko praćenje radi ranog dokazivanja i liječenja latentno invadiranih životinja.

Ključne riječi: koze; PCR-RFLP; Theileria ovis; T. lestoquardi; T. luwenshuni; Indija 